\title{
Peculiarities of manifesting hyperactivity by junior school age children
}

\author{
O. Chebykin, A. Yacishina
}

\author{
South-Ukrainian National Pedagogical University named after K. D. Ushynsky, Odessa, Ukraine, \\ Corresponding author. E-mail: yacishina93@gmail.com
}

Paper received 25.07.18; Accepted for publication 01.08.18.

https://doi.org/10.31174/SEND-PP2018-173VI71-11

\begin{abstract}
The paper is devoted to an extremely topical both in the theoretical and applied aspects subject. The aim of the work was to study the peculiarities of the manifestation of hyperactivity in junior school age children. The urgency of this problem is primarily due to the fact that the schoolchildren's hyperactivity is quite common phenomenon which complicates the educational process. Several stages in the history of hyperactivity cognition are analyzed: pre-scientific and comprehension of the problem of hyperactivity and ways of overcoming it in psychological and pedagogical studies. The paper reveals the psychological essence of the content of hyperactivity, highlights its main features, and presents co-authored with the scientific advisor comprehensive methodology and its diagnostics. The key feature in the content is excessive mobility, which can both mobilize and disorganize the the child's activity. At the same time, although it is natural for all the children, in some of them it appears situationally, and in others it can be long-termed. In the study, the respondents were divided into the following groups: sex, age, full or one-parent family, high and low social care of parents, children with high, mid and low levels of hyperactivity. The presented empirical data regarding the manifestation of hyperactivity in children of junior school age depending on their sex are significantly different. The suggested ideas can be used by both scholars and practitioners, psychologists or educators. The methods and technologies of prevention and correction of hyperactivity are indicated. The obtained results can be used in practice and the theory of modern psychological studies.
\end{abstract}

Keywords: hyperactivity, excessive mobility, children of junior school age, emotionality, attention deficit.

Introduction. The problem of hyperactivity in psychology is quite relevant and not fully disclosed. The vast majority of studies used the meaning of hyperactivity indirectly, while studying other phenomena. Herewith, practical queries to reveal the essence of this phenomenon, its emergency, manifestation and correction, remain not fully investigated. It is the lack of clear understanding of the content of this phenomenon and its features that complicates this process. Especially important is the cognition of the psychological characteristics of hyperactivity in a certain age period of children's development which is emphasized in numerous studies. One conception says that the development of personality is the formation of the ability to control their own behavior and mental processes. [4] The problem of hyperactive children sounds like a problem of uncontrolled, "difficult children", who have problems with their behavior organization, which, in its turn, causes problems in the process of interaction with peers and adults. The above mentioned features are an indicator of the arbitrariness development, and the domestic child psychology considers the arbitrariness development as the main and central line of of the child's personality development.

Purpose of the article. Based on the aforementioned, the paper aims at studying the peculiarities of manifesting hyperactivity by junior school age children.

Problem Statement. To achieve the given aim, the following tasks were set: to reveal the psychological essence of the content of hyperactivity; to generalize and systematize the features that characterize hyperactivity in junior school age children; to construct the methodology for diagnosing the features of hyperactivity, and to investigate the peculiarities of its manifestation in children depending on their age, sex, full or one-parent family and social care of their parents; to determine psychological technologies for hyperactivity correction.
To achieve the aim and solve the tasks, the following methods were employed: theoretical (analysis of domestic and foreign scientific sources, generalization of conceptions and approaches which make basis of hyperactivity); empirical methods (observation of school children's behavior in the classroom) and use of the expert assessment questionnaire on the hyperactivity manifestations in the junior school age children worked out with the scientific advisor as a co-author; methods of statistical data processing (determining statistically relevant values with the help of the t-criterion of Student; for this purpose the SPSS 13.0 software for Windows was used).

The methodological basis. The methodological basis of the study consists of: clarification of the categorical apparatus and the construction of both holistic and fragmentary theoretical models of hyperactivity cognition [2]; generalization of psychological features of hyperactivity, development of methods for its detection [3]; study of the phenomenon of both external and internal factors influencing the children's hyperactivity [4]; development of professional technology for correcting hyperactivity in children [1].

The conducted analysis of various studies shows that it is tentatively possible to distinguish several approaches to understanding the content of hyperactivity. Thus, some researchers [Karvasarskyi, 1989) believe that hyperactivity is a purely physiological process, caused by the development of certain physiological formations, such as: glands of the internal secretion, etc. This approach allows the authors to consider hyperactivity as a certain increased activity of psychophysiological functions.

Other scholars [7, p. 30] emphasize purely cognitive processes related to the inclusion of a child in a social environment $[8$, p. 23]. It is underlined that these are two mutually conditioned processes that characterize extreme activeness, not only in the child's physical actions, but also in actions related to the cognitive process. 
Another specialists [10, p. 73] believe that hyperactivity is a phenomenon of society urbanization, an evolutionary component of the development of mankind, caused by different conditions of life. That is, by environmental, social ones, etc. In this case, the key factor is the person's external conditions: to be extremely active in order to survive and to be successful in the activity. Some other speciaists [11] consider hyperactivity as an integrative entity, determined by various factors, which, under certain conditions, may be different.

Generalization of these studies shows that some researchers mainly emphasize the relevance of this problem, noting that in some cases it is a positive phenomenon of child's psychological development [16, p. 58], in others - a disorganizing one (Ratanova, Shliakhta, 1998 , p. 45). In other studies it is argued that the most sensitive periods or peaks of sensitive age is the period of preschool and junior school age [15, p. 64]. It can also be mentioned that at the junior school age, the range of factors influencing the emotional sphere is substantially expanding. The factors of the organization of educational process and the factors of informal relations with peers come to the fore [25].

Taking into account the above mentioned analysis, we will consider the content of hyperactivity as an excessive mobility and activeness of the child, which can mobilize their activity. Although it is natural for all children, but in some of them it manifests itself situationally, while in others it can be long-termed.

There are some data on the relationship of hyperactivity with the development of cognitive processes, such as disturbances of attention, emotional sphere, etc. [14, p. 67].

Solving the first task, based on the generalization of various data, we conditionally distinguished several stages in understanding the problem of children hyperactivity in the historical context:

The first stage (XIX century BC $-\mathrm{XX}$ century BC), which we conventionally named a pre-scientific stage, proved that the problem of hyperactive behavior of the child has been urgent from ancient times. Thus, in the book "Disadvantages in the child's character. The second golden book", a group of children was distinguished and described, they were called "restless, difficult children" [18, p. 75].

According to F. Scholz, a hyperactive child differs from others by the fact that his mobility extends mainly to the whole organism. Arms and legs are in random restless movement, but children perform these movements not firmly and confidently, but they rather rush to various directions and their awkwardness only complicates the matter. Such children can be called "trembling", and talkativeness is nothing more than the transference of muscular restlessness to the sphere of language [24, p. 5].

Having analyzed the literature, we distinguished three types of concepts: hyperactivity, attention deficit disorder (ADD) and mixed type (ADHD). From the perspective of different researchers, hyperactivity at the behavioral level leads to a combination of such symptoms as: agility, impulsivity, increased motor activity, which leads to severe difficulties in the organization of learning activity and socialization. Children with hyperactivity are unable to maintain focus on the task, because they do not receive enough reinforcements from it and have to switch to outside stimuli to get reinforcements from them and to keep a general mental tonus and activeness at an adequate level. Hyperactive children, being constantly in motion, can talk without a stop in contrast to attention deficit disorder, where a leading cognitive disturbance is a weakness of working memory - another component of controlling functions. Children with ADD easily overcome even strong distracting factors and can work at high speed if they enjoy the very procedural moments of their activity. But these children are innattentive, slow, unable to concentrate on something if it is not interesting for them. Also, there is a mixed type, it occurs most often, that is why the disturbances are often called the syndrome of attention deficit hyperactivity disorder. Different correlation of these concepts and a number of additional manifestations allow to distibguish different variants of hyperactivity, according to which differentiated work should be done.

Recently, researchers [20, p. 20] have argued that the main feature of increased activity in a child is a complication due to a deficit of attention and mood of the child. Based on the summary of literature data, the following peculiarities may be distinguished: first of all, those connected with the locomotor development: the inconvenience of movement; disturbance of coordination and harmony of motor complexes; general increased activity, difficulty in mastering movements; secondly, peculiarities of attention and control: problems with attention concentration, its dispersion etc.; thirdly, the peculiarities of the emotional sphere: anxiety, apathy, internal tension, emotional lability, mood change, negativism, feelings of fear, aggressiveness.

In the work of D. Dobson, hyperactive behavior and manifestation of increased activity are considered as a disease or an illness [6, p. 138]. Increased motor activity is not controlled, includes the tendency of the child to be distracted quickly, to be in a constantly restless state and inability to perform movement, concentration of attention. Such children may also have problems of visual perception, that is in the inability to correctly perceive the content of the symbol and the printed material, as well as emotional problems; in the presence of the latter, the disease is difficult to treat.

The second stage (XX century BC - XXI century BC) we defined conditionally as comprehending of the problem of hyperactivity in psychological and pedagogical studies and ways to solve it. There are some efforts to relate hyperactivity to certain individual psychological peculiarities of the child [5, p. 90). Attempts are made to characterize certain features of hyperactivity at the level of different types of the child's activity [22].

From the point of view of E. E. Sapokhova, children are divided into two categories. One of them includes excessively noisy, brave, agile, uncontrollable, naughty children; the other one is formed by sluggish, slow, quiet, tearful, capricious, stubborn, not outgoing chidren [27, p. 35].

From the perspective of other researchers [28, p. 108], hyperactivity manifests itself in excessive motor activity, independent of age and sex. It is argued in the works (E. M. Mostiukova, H. V. Gribonova, A. H. Moskovkina), (that children whose parents are alcohol-dependent, have a syndrome of increased excitability and motor deflection [26]. 
Based on the analysis of research by V. D. Yeremeieva, one can say that there is a dependence of the modality of emotional manifestations on the work of the left and right hemispheres of the brain. The research revealed that in the group of children with an evident superiority of the right hand, $1.5-2$ times more often passive types of emotions may occur; in another group, with a low degree of subordination of the right hand such active types of emotions are observed 2-3 times more often. At the same time, it turned out that the first group was marked by domination of slow children, and the second group - fast, active ones [12, p. 34].

Particular attention should also be paid to the studies [31], which underline that restlessness, motor anxiety are more clearly observed in boys than in girls, and that this is all due to the peculiar brain organization of neuropsychological processes and increased vulnerability of left-handed people in relation to psycho-traumatic factors.

Among the causes of hyperactivity, V. Krasov, considered hyperdynamic syndrome as a combination of actual motor breakdown, increased abstraction of various emotional and volitional disorders.

Based on the generalization of these and other studies, this period can be taken into account as a transition point where various experts have already stated hyperactivity and made attempts to explain the mechanisms underlying this phenomenon at the theoretical level.

In most studies, hyperactivity is seen in the form of a number of symptoms, among which the most common are different variants of the combination of three of them: excessive motor activity, impaired emotional behavior and lack of attention. Different correlation of these symptoms and a number of additional manifestations allow to assume different variants of hyperactivity, according to which differentiated work should be constructed.

According to the third task, it is necessary to disclose and systematize the existing psychological technologies for the correction of children's hyperactive behavior. It can be argued that the research carried out in this plan has shown that there are different tendencies of solving this issue in modern psychology. So, the most common are: medical therapy (psychostimulants); psychotherapy (meditation, autogenous training, family psychotherapy, behavioral therapy); special training (correction classes).

Among psycho-pedagogical methods of hyperactive behavior correction, the main role is given to behavioral psychotherapy. Behavioral programs require considerable skills, adults have to employ their imagination and experience of communicating with children in order to support the child's motivation during classes. Correctional techniques will only be effective if family and school work closely together, which should include sharing information by parents and teachers through joint seminars, training courses, etc. Success will be guaranteed only if common principles in relation to a child both at home and at school are kept to: a system of "rewards", adults' assistance and support, participation in joint activities. "Thus, the formation of moral values can be disclosed through a special, inherent in a certain age period form of communication. Formation of moral values involves changes in the emotional, volitional, cognitive, activity spheres of personality" [19].
Other scholars [23] offer motor activity. Correction of hyperactive children must necessarily include physical rehabilitation. These are special exercises aimed at renewing behavioral reactions, developing coordinated movements with arbitrary relaxation of skeletal and respiratory muscles.

Based on summary of these and other studies, the following psychotherapeutic techniques can be distinguished: a) visualization - creating conditions for the restoration of mental and physical balance; b) meditation reduces the activity of the sympathetic system, promotes decrease in anxiety and relaxation. At the same time the heart rate and breathing slow down, the need for oxygen decreases, the picture of brain tension changes, the reaction to the stressful situation gets balanced; c) autogenous training - helps to reduce motor breakdown, emotional excitability, improve coordination in space, motor control, increases concentration of attention; d) family psychotherapy - necessary for parents who are guilty of "bad" upbringing of the child, and for the child themselves.

Based on the above said, the respondents for our study were selected among the children aged 7 to 12 .

Summarizing the foregoing, it can be concluded that the manifestation of child's hyperactive behavior covers several spheres, among which the most common are different variants of the combination of the three symptoms: excessive motor activity with a lack of motor coordination; disturbance of emotional behavior - rapid mood change; attention deficit.

Results and Discussion. To find out the peculiarities of the manifestation of children's hyperactive behavior, we conducted a preliminary study. While developing the questionnaire, we analyzed more than 50 different methods and studies. One of them is the study (Briazhunova I. P. and Kasatikova Ye. V.) on the detection of hyperactivity in primary school children. For teachers, the questionnaire with a list of such questions was offered: 1) a child is fussy; 2) unable to sit in one place; 3) moves a lot, but spontaneously (running, spinning); 4) can not quietly play or engage in anything at leisure; 5) the child is always aimed at movement; 6) talkative; 7) often begins to answer, without thinking or even listening to the question; 8) looking forward to their turn in different situations; 9) in a conversation often interrupts, interferes with others. In the presence of a pronounced symptom, the teacher was to indicate the degree of its severity in the questionnaire in points: 0 - the absence of signs; 1 - the presence is insignificant; 2 - present in a moderate degree; 3 - present in a pronounced degree. The research showed that according to the answers of respondents, the signs of hyperactivity were found in 5 children from 28 . A more pronounced sign of hyperactivity was talkativeness and fussiness.

For the following work, in cooperation with the scientific advisor, a questionnaire for teachers was developed. According to the questionnaire, an expert assessment of the manifestation of various signs of children's hyperactivity in the classroom was carried out. The questionnaire included statements, which determined 10 features of hyperactivity: emotionality, mobility, liability to divert attention, sensitivity, excitability, attentiveness, working capacity, mental instability, diligence, ostentation. These features were chosen by means of the expert selection of those 
statements which were the most adequate for the age of the pupils. Teachers were invited to evaluate the manifestation of children's hyperactivity in the classroom. Subsequently, the results were translated into the following points: $0-4$ points - almost no manifestations of hyperactivity, 5-7 points - manifestations are present to a small extent, 8-10 points - pronounced manifestations of hyperactivity. 8 pedagogues having working experience of more than 10 years were invited, and also children aged 7-8 (89 children), 9-10 (110 children) and 11-12 (29 children). The analysis of the results was carried out by comparing the groups with different levels of hyperactivity, as well as taking into account the age and gender of children, their family status (full or incomplete, one-parent family), and the level of social care (high or low).

The results obtained during the empirical study, allowed to select from the general sample, three groups of respondents according to the level of manifestation of hyperactivity. The first group of children, expert assessments for which by most values that characterize hyperactivity are at a minimum level, was called with a low level of its manifestation (19\%). The second group, with the prevailing points that characterize the manifestations of hyperactivity to a small extent, was called a group with a mid level of hyperactivity manifestation (37\%). The third group is children with a predominantly high level of hyperactivity (44\%).

The comparison of diagnosed values in selected groups of respondents showed that there are certain differences (Fig. 1).

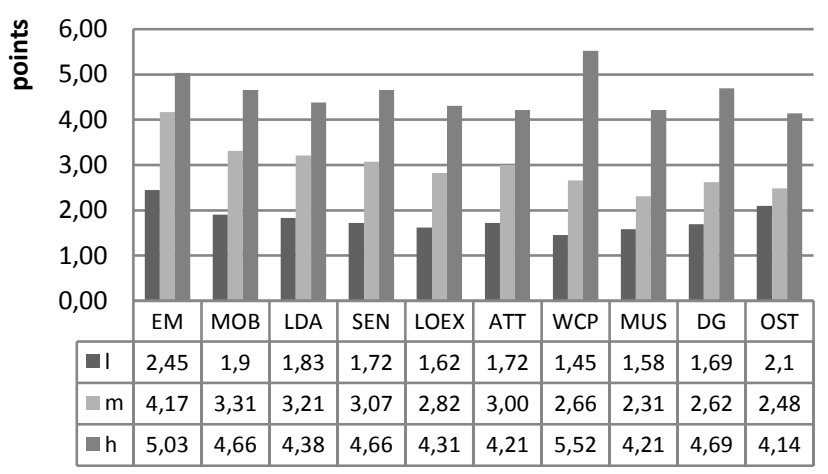

Fig. 1. Average values of indices characterizing features of hyperactivity in children with different levels of its manifestation EM - emotionality, MOB - mobility, LDA - liability to divert attention, SEN - sensitivity, LOEX - liability to overexcitement, ATT - attentiveness, WCP - working capacity, MIS - mental instability, DG - diligence, OST - ostentation;

1 - low level of hyperactivity, $\mathrm{m}$ - mid level of hyperactivity, $\mathrm{h}$ - high level of hyperactivity

Thus, the comparison of mean values by the index of EM (emotionality) showed that its highest manifestation was observed in the group of children with high hyperactivity $(\overline{\mathrm{X}}=5.03)$, which is 0.86 points higher than in children with moderate hyperactivity, and 2,58 points higher than in the children with low hyperactivity. Among the mean values of this index in the groups with mid and low levels of hyperactivity the difference was 1.72 points. The statistical verification of these differences, which was carried out according to the Student's t-criterion, demonstrated that these differences can be considered significant $(\mathrm{t}=4.39 ; \mathrm{p} \leq 0.01)$. Consequently, high emotionality characterized by high emotional instability, frequent mood changes, a liability to short-term and strong affects distinguishes hyperactive children from non-hyperactive ones.

Mean values of the MOB (mobility) index in the group of children with high hyperactivity $(\bar{X}=4.66)$ are 1.35 points higher than in children with moderate hyperactivity and 2.76 points higher than in the group of children with low hyperactivity. However, the statistical check of the above-mentioned differences revealed that they can not be considered significant due to the high intragroup variability of expert assessments. Consequently, although mobility can characterize the behavior of children in terms of their hyperactivity, but is not a significant criterion by which it can be diagnosed.

As fas as the LDA (liability to divert attention) index is concerned, it is the highest in the group of children with high hyperactivity $(\overline{\mathrm{X}}=4.38)$, which is 1.17 points higher than in children with moderate hyperactivity, and 2.55 points higher than in the group with low hyperactivity. Statistical analysis of these differences showed that the differences between the groups with high and low hyperactivity $(t=2,24 ; p \leq 0,05)$ can be considered significant, which allows us to conclude that discontinuity characterized by inadequacy, switching to other situations with complete distraction from the activity can be considered an essential feature by which hyperactive children are distinguished from non-hyperactive ones.

The SEN (sensitivity) index is represented by the data that are highest in the group of children with high hyperactivity $(\overline{\mathrm{X}}=4.66)$, which is on average 1.59 points higher than in children with moderate hyperactivity, and 2.94 points higher than in the group with low hyperactivity. However, during the statistical check, these differences turned out to be not significant, which allows to consider sensitivity as additional feature that characterizes the behavior of children in terms of excessive sensitivity to various external stimuli and other people.

Comparison of mean values by the index of EXC (excitability) proved that its manifestation in the group of children with high hyperactivity $(\overline{\mathrm{X}}=4.31)$ was 1.49 points higher than in children with moderate hyperactivity, and 2.69 points higher than in the group with low hyperactivity. However, as in the previous case, these differences were statistically insignificant, and, therefore, the excitability was attributed to additional features that characterize the hyperactive behavior of children.

As fas as the ATT (attentiveness) index is concerned, it is also highest in the group of children with high hyperactivity $(\overline{\mathrm{X}}=4.21)$, which is 1.21 points higher than in children with moderate hyperactivity, and 2.49 points higher than in the group with low hyperactivity. Herewith, there are statistically significant differences between the groups with high and low hyperactivity $(\mathrm{t}=3.46 ; \mathrm{p} \leq 0.01)$, which allows to consider attentiveness characterized by the distraction in the perception of the situation, an inability to comprehend the situation in a holistic way and to concentrate on it is a significant feature by which hyperactive children can be differentiated from nonhyperactive ones.

Regarding the mean values of the WCP (working capacity) index, the highest ones were found in the group of children with high hyperactivity $(\bar{X}=5.52)$, which is 2.86 
points higher than in children with moderate hyperactivity and 4.07 points higher than in the group with low hyperactivity. The check of these differences according to $\mathrm{t}$-criterion showed that the differences between the groups with high and moderate hyperactivity were statistically significant $(\mathrm{t}=6.36 ; \mathrm{p} \leq 0.01)$. That is, significant fluctuations, decreases and increases in work capacity, fast tiredness are an essential feature that distinguishes hyperactive children.

The MIS (mental instability) index by the mean values is highest in the group of children with high hyperactivity $(\bar{X}=4.21)$, which is on average 1.9 points higher than in children with moderate hyperactivity and 2.63 points higher than in the group of children with low hyperactivity. During the statistical verification, the differences between the groups with high and low levels of hyperactivity were found to be significant $(t=2.85 ; \mathrm{p} \leq 0.01)$, which allows to consider mental instability characterized by conflict liability and inadequacy of the child's interaction with the teacher and the peers as essential feature of children's hyperactive behavior.

Comparison of mean values by the DG (diligence) index showed that its manifestation in the group of children with high hyperactivity $(\overline{\mathrm{X}}=4.49)$ was 2.07 points higher than in children with moderate hyperactivity, and 3 points higher than in the group of children with low hyperactivity. However, these differences were statistically insignificant, and, therefore, diligence can only indirectly characterize the hyperactive behavior of children.

The same conclusion can be drawn regarding the feature of ostentation. The manifestation of the relevant OST (ostentation) index in the group of children with high hyperactivity $(\overline{\mathrm{X}}=4.14)$ is 1.66 points higher than in children with moderate hyperactivity and 2.04 points higher than in the group of children with low hyperactivity. However, the differences appeared to be statistically insignificant, which allowed us to consider ostentation as a feature that can only indirectly characterize children's hyperactive behavior.

Thus, as statistical analysis of the differences in the studied indices in the groups of children with different levels of hyperactive behavior manifestation demonstrated, children with high level of hyperactivity differ significantly from non-hyperactive children with high emotionality (emotional instability, frequent mood changes, tendency to short-term and strong affects), distraction (inadequacy, switching to other situations with complete distraction from the activity), inattentiveness (distraction in the perception of the situation, an inability to holistically comprehend the situation and focus on it), poor work capacity (significant fluctuations, decreases and increases in work capacity, fatigue) and mental instability (conflicts and inadequate interaction with the teacher and the peers). It was statistically proved that these behavioral characteristics are essential features of hyperactivity in children. Additional features that can specify and clarify the nature of the behavioral hyperactivity manifestation include excessive mobility, sensitivity, excitability, indiligence, ostentation. The manifestation of these features can both occur in children with high hyperactivity and characterize the individual behavioral invariants of nonhyperactive children.
Further analysis was aimed to determine significant differences according to diagnosed indices depending on the respondents' sex (Fig. 2).

The data presented in the figure show that on average, all the features of hyperactivity in boys have a somewhat more significant manifestation than in girls, which is proved by the pronounced relevant indices, that are higher in the group of boys, namely: the index of EM (emotionality) by 0,71 points, the index of mobility (mobility) by 0.53 points, the index of LDA (liability to divert attention) by 0.41 points, the SEN (sensitivity) index by 0.43 points, the ESC (excitability) index by 0.54 points, the ATT index (attentiveness) by 0.51 points, the index of WCP (working capacity) by 0.14 points, the MIS (mental instability) by 0.48 points, the DG (diligence) index by 0.39 points, the OST (ostentation) index by 0.41 points. However, these differences between boys and girls in any of the indices did not receive a statistical confirmation of their significance when employing the t-criterion of Student. This makes it possible to conclude that there are no significant differences in the manifestation of the features of hyperactivity depending on the sex of children, and also to note only a slight excess of manifestations of hyperactive behavior in boys compared with girls.

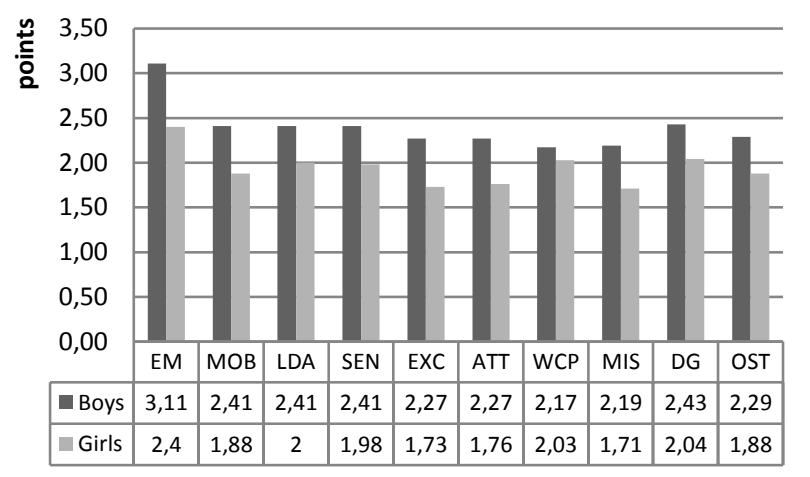

Fig. 2. Average values of indices characterizing the features of hyperactivity in children depending on their sex

Considering the differences in diagnosed indices depending on the respondents' age, it can be seen that they are virtually absent (Fig. 3).

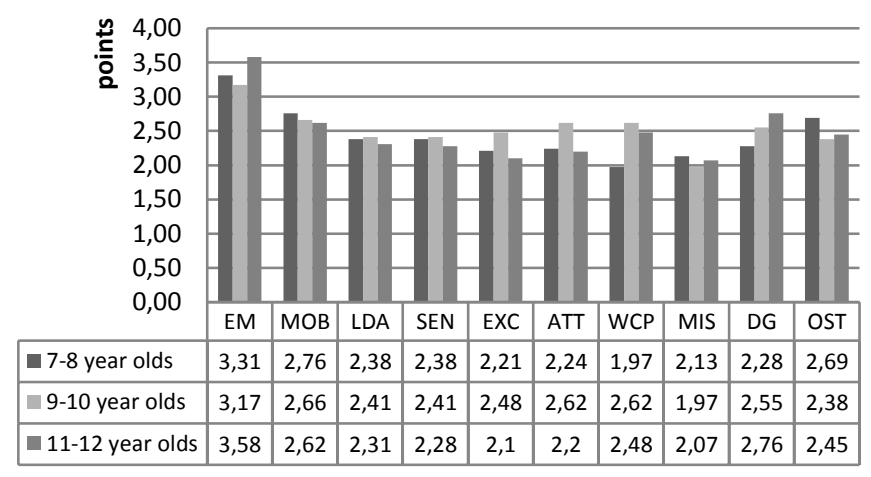

Fig. 3. Average values of indices characterizing features of hyperactivity in children of different age

The data presented in the figure show only slight fluctuations in the average values of indices that characterize the manifestations of hyperactive behavior of children at different age periods, and these fluctuations do not have a definite orientation towards the dynamics of 
hyperactivity in the long run. Thus, by the indicator of EM (emotionality), the greatest difference is only 0.41 points, according to the MOB (mobility) index -0.14 points, according to the LDA index (liability to divert attention) 0.1 point, according to the SEN (sensitivity) index $-0,13$ points, according to the EXC (excitability) -0.38 points, according to the ATT index (attentiveness) -0.42 points, according to the WCP index (working capacity) -0.65 points, according to the MIS (mental instability) index 0.16 points, according to the DG (diligence) index $-0,48$ points, according to the OST (ostentation) index $-0,24$ points. In addition, the statistical check of these and other differences between the three age groups did not confirm their statistical validity by any of the indices, and, therefore, the age period of 7 to 12 is not sensitive to changes in the manifestation of children's hyperactive behavior. At the same time, considering the child's hyperactivity as a natural process of children's mental activity, it can be concluded that its dynamics of changes depends more on social conditions of personality development, namely, the peculiarities of the educational process in the family and in school.

To reveal the specifics of hyperactivity manifestation depending on the conditions of family upbringing, we carried out a comparison of the studied indices between children from two- and one-parent families, as well as between children whose parents show different levels of social care.

First, let us consider the data on manifesting indices of hyperactivity in children who are raised in two-parent and one-parent families (Fig. 4).

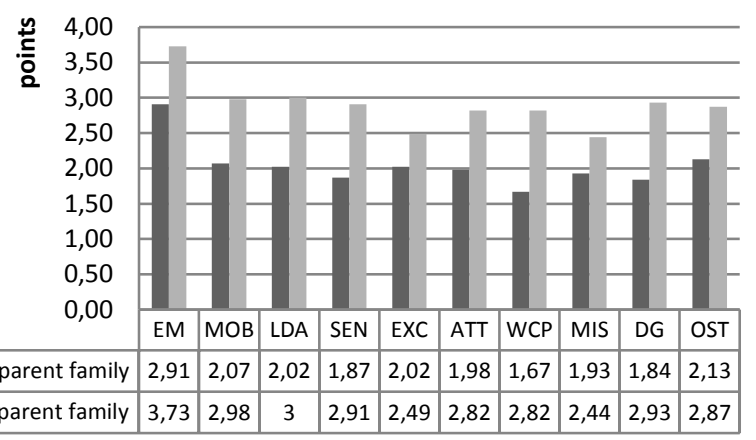

Fig. 4. Average values of indices characterizing features of hyperactivity in children from two-parent and one-parent families

The figure illustrates the fact that, on average, by all the indices of hyperactivity, children from one-parent families show a more significant manifestation of hyperactive behavior than children who are raised in full families. In particular, according to the EM (emotionality) index, the excess of the manifestation is on average 0.82 points, according to the MOB (mobility) index -0.91 points, according to LDA (liability to divert attention) index -0.98 points, according to the SEN (sensitivity) indicator - 1,04 points, according to the EXC index (excitability) - 0,47 points, according to the ATT (attentiveness) index - 0,84 points, according to the WCP (working capacity) index 1,15 points, according to MIS (mental instability) index 0,51 points, according to the DG (diligence) index $-1,09$ points, according to the OST (ostentation) index $-0,74$ points. Herewith, statistical verification of the indicated differences did not confirm their validity by most indices. The exception is the index of EXC (excitability) with $\mathrm{t}=$ 2,24 at $p \leq 0,05$. Consequently, the specifics of hyperactivity manifestation in children from one-parent families is characterized primarily by excessive stress. Although, in general, children from one-parent families have more expressive signs of hyperactivity than children from full families, but no significant difference in its overall manifestation was revealed.

Regarding the dependence of children's behavioral hyperactivity manifestations in the group of children on the level of their parents' social care, we should note that we understood it as the care of parents, the frequency of attending parental meetings, and interest in the school performance of their children. According to these parameters of parents' social care, the sample of respondents was divided into two groups: children whose parents show high level of social care, and children whose parents show low level of social care. Let us consider the average indices that characterize the manifestation of hyperactivity in these groups (Fig. 5).

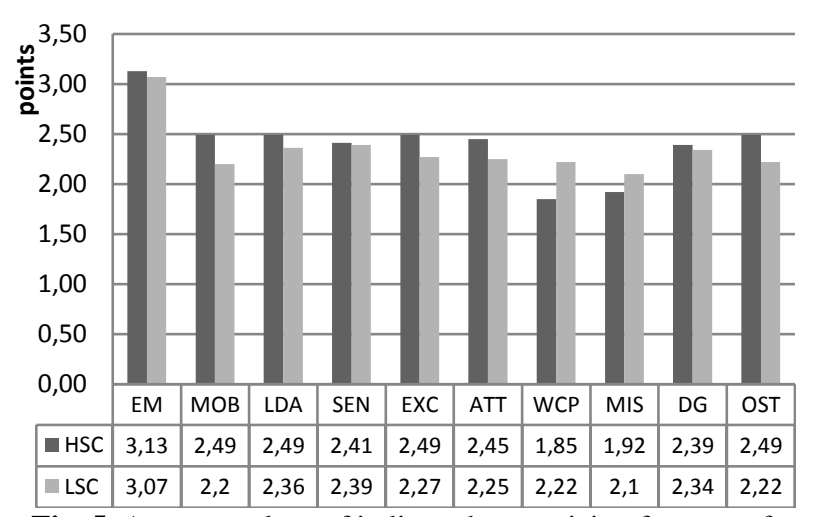

Fig. 5. Average values of indices characterizing features of hyperactivity in children depending on the level of parents' social care

HSC - children, whose parents show high level of social care, LSC - children, whose parents show low level of social care.

The data presented demonstrate that according to most indices, the average values in the formed groups differ insignificantly. There are slight differences showing that children whose parents show high level of social care, have on average higher expert assessment according to some indices than children from families with low level of parents' social care, namely, according to the index of EM (emotionality) - 0.06 points, according to the MOB (mobility) index -0.29 points, according to the LDA (liability to divert attention) index -0.13 points, according to the SEN (sensitivity) index -0.02 points, according to the EXC (excitability) index -0.22 points, according to ATT (attentiveness) index -0.2 points, according to the DG (diligence) index -0.05 points, according to the OST (ostentation) index -0.27 points. At the same time, according to the rest of the indices, average manifestation of hyperactivity was higher in the group of children whose parents show low level of social care, namely, by the WCP (working capacity) index - by 0.375 points and by the MIS (mental instability) index -0.18 points. It should also be noted that only differences in the SEN (sensitivity) index $(\mathrm{t}$ $=1.98 ; \mathrm{p} \leq 0.05)$ and the $\mathrm{DG}$ (diligence) index $(\mathrm{z}=1.87$; $\mathrm{p} \leq 0.05)$ turned out to be statistically significant. Therefore, 
children whose parents show high level of social care are characterized by more pronounced sensitivity to various external stimuli and other people, as well as by the inability to self-organization, concentration.

Summarizing the results of the study presented above, we can say that according to the average indices various features of hyperactivity are quite common among the children aged 7 to 12 , at the same time the level of their manifestation is in the range of average values, that is, their hyperactivity does not go beyond significant manifestation. Moreover, hyperactivity tends to increase with age, with the effect of excessive parental care leading to an increase in the severity of certain features of hyperactivity in children.

Conclusions. Thus, according to the results of the study, the following conclusions can be drawn:

1. It is shown that the problem of hyperactivity in psychology is rather relevant and insufficiently studied. The vast majority of studies have used hyperactive values indirectly when investigating other phenomena;

2. Summarizing the information obtained in psychology and our own empirical research, it is possible to determine hyperactivity as an excessive mobility and activiness of a child that can mobilize or disrupt their activity. At the same time, although it is natural for all children, but in some of them it manifests itself situationally, while in others it may be long-termed;

3. The reasons for the hyperactivity emergence were revealed: genetic predisposition, individual features of the nervous system, environment, society;

4. In collaboration with the scientific advisor, a questionnaire of expert assessment was developed, showing the various peculiarities of hyperactivity in the classroom. The most informative in this regard were the following peculiarities of hyperactivity: emotionality, mobility, liability to divert attention, sensitivity, excitability, attentiveness, work capacity, mental instability, diligence, ostentation;
5. A comparative analysis of the obtained results provided us with an opportunity to determine the difference between the indices of hyperactivity. The most significant features with different levels of its manifestation are: the EM (emotionality) index. Consequently, high emotionality characterized by a large emotional instability, frequent mood changes, a tendency to short-term and strong affects distinguishes hyperactive children from non-hyperactive ones

6. The obtained indices characterizing the features of hyperactivity of children of different age show only insignificant fluctuations in the mean of the indices' values whose difference of which is not statistically verified. Moreover, these fluctuations do not have a definite orientation towards the dynamics of hyperactivity in the long run. In addition, the statistical verification of these and other differences between the three age groups by any of the indices did not confirm their statistical validity, and therefore the age range of 7 to 12 is not sensitive to changes in the manifestation of hyperactive behavior of children. At the same time, considering the child's hyperactivity as a natural process of children's mental activity, it can be seen that the dynamics of its changes to a greater extent depends on social conditions of personality development, namely, on the peculiarities of the educational process in the family and in the school;

7. The carried out research proved that there are different psychological technologies of correction of hyperactivity in modern psychology. So, the most common are: medical therapy (psychostimulants); psychotherapy (meditation, autogenous training, family psychotherapy, behavioral therapy); special training (correction classes).

The prospect for further research is the study of the hyperactivity level formation and its positive or negative influence on the child's activity.

\section{ЛІТЕРАТУРА}

1. Ануфриев А. Ф. Костромина С. Н., “Как преодолеть трудности в обучении детей. Психодиагностические таблицы. Психодиагностические методики. Коррекционные упражнения" - 3-е изд., перераб. и доп., $2000,111 \mathrm{c}$.

2. Бадалян Л. О., “Детская неврология”, 1984, 380 с.

3. Брязгунов И. П., Касатикова Е. В. "Непоседливый ребенок, или все о гиперактивных детях", 2001, 27 с.

4. Выготский Л. С., “Проблемы развития психики”, Собр. соч. т.3., 1983, С.144-146, 207, 293.

5. Гаспарова Е. М., “Шустрики» и «Мямлики”, Дошкольное воспитание, № 4, 1990, С. 90-98

6. Добсон А., "Непослушный ребенок”, 1992, С. 131-149

7. Заваденко Н. Н., “Как понять ребенка: дети с гиперактивностью и дефицитом внимания", 2000, С. 1-34

8. Захаров А. И., “Как предупредить отклонения в поведении ребенка", 1980, 23 с.

9. Карвасарский Б. Д., "Психотерапевтическая энциклопедия”, (Серия«Мастера психологии»), СПб.: Питер, 1998, 55 с.

10. Кошолева А. Д., “Взаимодействие «взрослый-ребенок» и функциональная роль эмоциональных процессов в онтогенезе", Проблемы гуманизации воспитательнообразовательного прочесса в детском саду, Пермь, 1993, C. $73-87$

11. Красов В. А., “Гипердинамический синдром у детей младшего школьного возраста", автореф.дис.канд.мед.наук, 1989, 20 с.

12. Локалова Н. П., “ 120 уроков психологического развития младших школьников”: изд. 2-ое, 2000, 34 с.

13. Лютова Е. К., Монина Г. Б., "Тренинг эффективного взаимодействия с детьми”, СПб.: Питер, 2000, 67 с.

14. Обухова Л. Ф., “Детская психология: теория, факты проблемы”, 1995, 64 с.

15. “Особенности психологического развития детей 6-7летнего возраста”, Под ред. Эльконина Д. Б., Венгера А. Л., 1988, 58 c.

16. Ратанова Т. А., Шляхта Н. Ф., “Психодиагностические методы изучения личности", 1998, с. 45

17. Роджерс К. Р., “Консультирование и психотерапия”,2000, $75 \mathrm{c}$.

18. Федорова М. А., “Обгрунтування структурних характеристик моральних цінностей дітей старшого дошкільного віку”, Наука і освіта / Scince and Education - 2016 - № 9 (32) [Електронний pecypc]. Доступно: https://doi.org/10.24195/2414-4665-2016-9-32

19. Холёва Л. А., "Влияние семейных отношений на формирование личности дошкольника”, С. 20-34.

20. Цапкиня В. Н., "Единство и многообразие психотерапевтического опыта", Психологическое консультирование и психотерапия, т.1, 1999, 67 с. 
21. Шевченко Ю. С., “Коррекция поведения детей с гиперактивностью и психоподобным синдромом”, 1997, $21 \mathrm{c}$.

22. Шольц Ф., "Недостатки в характере ребенка или Вторая золотая Книжка", Киев, 1983, 5 с.

23. Чебыкин А. Я., "Генезис эмоциональных особенностей у детей разного возраста и пола": [монография] / А. Я. Чебыкин, И. В. Мельничук. - Одесса : [ЮНЦ АПН Украины], 2004. - 147 с.

24. Эльконин Д. Б., "Психология обучения младшего школьника", 1974, 64 с.

25. Лебединский В., Никольский О. С., Баенская Е. Р., Либлины М. М., "ЭМоциональные нарушения в детском возрасте и их коррекция”, 1990, С. 34-60
26. Яскова О., “Гиперактивность как психологический диагноз: особенности гиперактивного ребенка”, 2009, № 8, C. $108-113$.

27. A. Chad, PhD. Noggle, S. Raymond, PhD. Dean, ABPP, ABPN, Arthur MacNeill Horton Jr., EdD, ABPP, ABPN. The Encylopedia of Neuropsychological Disorders. Attention Deficit Hyperactivity Discorder, 2012, pp. 120-124

28. H.B.Vidair, J.A. Reyes, S. Shen, M.A. Parrilla-Escobar, C.M. Heleniak, I.L. Hollin, "Screening parents during child evaluations: Exploring parent and child psychopathology in the same clinic". Journal of the American Academy of Child and Adolescent Psychiatry, 50 (5), 2011, pp. 441-450

29. K.S.Wang, X.Liu, Q. Zhang, N.Aragam \& Y. Pan, "Parent-oforigin effects of FAS and PDLIM 1in attention deficit, hyperactivity disorder", Journal of Psychiatry and Neuroscience: JPN, 37 (1), 2012, pp. 46-52

\section{REFERENCES:}

1. Anufriyev, A. F., Kostromina, S. N. (2000). Kak preodolet trudnosti v obuchenii detey. Psikhodiagnosticheskiye tablitsy. Psikhodiagnosticheskiye metodiki. Korrektsionnyye uprazhneniya [How to overcome difficulties in teaching children. Psychodiagnostoc tables. Psychodiagnostic methods. Correction exercises] (3d ed., rev.) Moscow: Os-89.

2. Badalian, L. O. (1984). Detskaya nevrologiya [Child's neurology] (3d ed., rev.). Moscow: Medicine.

3. Briazgunov, I. P., Kasatikova, Ye. V. (2001). Neposedlivyy rebionok, ili vsio o giperaktivnykh detiakh [Restless child or everything about hyperactive children]. Moscow: Izdetelstvo instituta psikhoterapii.

4. Vygotskiy, L. S. (1983). Problemy razvitiya psikhiki [Problems of psyche development]. Moscow: Pedagogika.

5. Gasparova, Ye. M. (1990). "Shustriki" i "miamliki" [Sharp and slow lads]. Doshkolnoye vospitaniye - Pre-school education, 4, 90-98.

6. Dobson, A. (1992). Neposlushnyi rebionok [A nasty child]. Moscow: Mirt.

7. Zavadenko, N. N. (2000). Kak poniat rebionka: deti s giperaktivnostyu i defitsitom vnimaniya [How to understand a child: children with hyperactivity and attention deficit]. Moscow: Shkolnaia pressa.

8. Zakharov, A. I. (1980). Kak predupredit otkloneniya v povedenii rebionka [How to prevent the deviations of child's behavior]. Moscow: Prosveshcheniye.

9. Karvasarskiy, B. D. (1988). Psikhoterapevticheskaya entsiklopediya [Psychotherapy encyclopedia] (2nd ed.). Saint-Petersburg: Piter.

10. Kosholeva, A. D. (1993). Vzaimodeistviye "vzroslyi-rebionok" i funktsionalnaya rol emotsionalnykh protsessov $\mathrm{v}$ ontogeneze" [Interaction "adult-child" and functional role of emotional processes in onthogenesis]. Problemy gumanizatsii vospitatelno-obrazovatelnogo protsessa $v$ detskom sadu Problems of humanization of educational process in nursery school, (pp.73-87).

11. Krasov, V. A. (1989). Giperdinamicheskiy sindrom u detey mladshego shkolnogo vozrasta [Hyperdynamic syndrome in junior school age children]. Moscow.

12. Lokalova, N. P. (2000). 120 urokov psikhologicheskogo razvitiya mladshykh shkolnikov [120 lessons of junior schoolchildren's psychological development] (2nd ed.). Moscow: Os-89.

13. Liutova, Ye. K., Monina, G. B. (2000). Trening effektivnogo vzaimodeistviya s detmi [Training in effective interaction with children]. Saint-Petersburg: Piter.

14. Obukhova, L. F. (1995). Detskaya psikhologiya: teoriya, fakty, problemy [Child psychology: theory, facts, problems] (3d ed.). Moscow: Trivola.
15. Elkonin, B. D., Venger, A. L. (Eds.). (1998). Osobennosti psikhologicheskogo razvitiya detey 6-7-letnego vozrasta [Peculiarities of psychological development of 6-7 aged children]. Moscow: Pedagogika.

16. Ratanova, T. A., Shliakhta, N. F. (2003). Psikhodiagnosticheskiye metody izycheniya lichnosti [Psychodidactic methods of personality studies] (3d ed., rev.). Moscow: MPSI - Flinta.

17. Rodgers, K. R. (2000). Konsultirovaniye i psikhoterapiya [Consulting and psychotherapy]. Moscow: EKSMO-Press.

18. Fedorova, M. A. (2016). Obgruntuvannia strukturnykh kharakterystyk moralnykh tsinnostey ditey starshoho doshkilnoho viku [Substantiation of structural charactersitcs of senior preschool age children]. Nauka i osvita - Science and education, 9 (32). Retrieved from: https://doi.org/10.24195/2414-46652016-9-32.

19. Kholiova, L. A. (1987). Vliyaniye semeynykh otnosheniy na formirovaniye lichnosti doshkolnika [Influence of family relationships on the pre-school pupil's personality formation]. Psikhologiya formirovaniya lichnosti detey doshkolnogo $i$ shkolnogo vozrastov - Psychology of developing personality of pre-school and school age children, 8, 20 - 34.

20. Tsapkinya, V. N. (1992). Yedinstvo i mnogoobraziye psikhoterapevticheskogo opyta [Unity and diversity of psychotherapeutic experience]. Psikhologicheskoye konsultirovaniye i psikhoterapiya - Psychological consulting and psychotherapy, 2, 67.

21. Shevchenko, Yu. S. (1997). Korrektsiya povedeniya detey s giperaktivnostyu $i$ psikhopodobnym sindromom: prakticheskoye rukovodstvo dlya vrachey, psikhologov i pedagogov [Correction of behavior of children with psyche-like syndrome: Instructions for doctors, psychologists and pedagogues] (2nd ed.). Moscow: Vita-Press.

22. Sholts, F. (1983). Nedostatki $v$ kharaktere rebionka ili Vtoraya zolotaya Knizhka [Drawbacks of child's character or Second golden Book]. Kyiv: Typ. N. Piliushchenko.

23. Chebykin, A. Ya., Melnichuk, I. V. (2004). Genezis emotsionalnykh osobennostey u detey raznogo vozrasta i pola [Genesis of emotional features in children of different age and sex]. Odessa: YuNTs APN Ukrainy.

24. Elkonin, D. B. (1974). Psikhologiya obucheniya mladshego shkolnika [Pcyhology of teaching junor pupils]. Pedagogika $i$ psikhologiya - Pedagogy and psychology, 10, 64.

25. Lebedinskiy, V., Nikolskiy, O. S., Bayenskaya, Ye. R., Libliny \& M. M. (1990). Emotsionalnyie narusheniya $v$ detskom vozraste i ikh korrektsiya [Emotional disturbances in child age and their correction]. Moscow.

26. Yaskova, O. (2009). Giperaktivnost kak psikhologicheskiy diagnoz: osobennosti giperaktivnogo rebionka [Hyperactivity as a psychological diagnosis: peculiarities of hyperactive child]. Doshkolnoye vospitaniye - Pre-school education, 8, 108-113. 